\title{
Organic acids enhance the uptake of lead by wheat roots
}

\author{
Huanhua Wang · Xiaoquan Shan · Tao Liu • \\ Yaning Xie - Bei Wen · Shuzhen Zhang · Fang Han • \\ Martinus Th. van Genuchten
}

Received: 25 July 2006/ Accepted: 23 October 2006/Published online: 15 November 2006

(C) Springer-Verlag 2006

\begin{abstract}
The uptake and bioavailability of lead $(\mathrm{Pb})$ in soil-plant systems remain poorly understood. This study indicates that acetic and malic acids enhance the uptake of $\mathrm{Pb}$ by wheat (Triticum aestivum L.) roots under hydroponic conditions. The net concentration-dependent uptake influx of $\mathrm{Pb}$ in the presence and absence of organic acids was characterized by Michaelis-Menten type nonsaturating kinetic curves that could be resolved into linear and saturable components. Fitted maximum uptake rates $\left(V_{\max }\right)$ of the Michaelis-Menton saturable component in the presence of acetic and malic acids were, respectively, 2.45 and 1.63 times those of the control, while the Michaelis-Menten $K_{\mathrm{m}}$ values of 5.5, 3.7 and $2.2 \mu \mathrm{M}$, respectively, remained unchanged. Enhanced $\mathrm{Pb}$ uptake by organic acids was partially mediated by $\mathrm{Ca}^{2+}$ and $\mathrm{K}^{+}$channels, and also depended upon the physiological function of the plasma membrane P-type ATPase. Uptake may have been further enhanced by an effectively thinner unstirred layer of
\end{abstract}

H. Wang $\cdot$ X. Shan $(\bowtie) \cdot$ B. Wen $\cdot$ S. Zhang .

F. Han

State Key Laboratory of Environmental Chemistry and

Ecotoxicology, Research Center for Eco-Environmental

Sciences, Chinese Academy of Sciences,

P. O. Box 2871, Beijing 100085, China

e-mail: xiaoquan@rcees.ac.cn

T. Liu · Y. Xie

Beijing Synchrotron Radiation Laboratory,

Institute of High Energy Physics,

Chinese Academy of Sciences, Beijing 100049, China

M. Th.van Genuchten

U.S. Salinity Laboratory, USDA-ARS,

450 West Big Springs Road, Riverside, CA 92501, USA
$\mathrm{Pb}$ adjacent to the roots, leading to more rapid diffusion towards roots. X-ray absorption spectroscopic studies provided evidence that the coordination environment of $\mathrm{Pb}$ in wheat roots was similar to that of $\mathrm{Pb}\left(\mathrm{CH}_{3} \mathrm{COO}\right)_{2} \cdot 3 \mathrm{H}_{2} \mathrm{O}$ in that one $\mathrm{Pb}$ atom was coordinated to four oxygen atoms via the carboxylate group.

Keywords $\mathrm{Ca}^{2+}$ and $\mathrm{K}^{+}$channels $\cdot$ Organic acids . P-type ATPase - Uptake of lead $(\mathrm{Pb}) \cdot$ Wheat (Triticum aestivum L.) · X-ray absorption spectroscopy

\section{Introduction}

Being one of the most frequently encountered metal contaminants in many agricultural and industrial areas, the environmental fate of $\mathrm{Pb}$ and its uptake by plants has been the subject of much research (Manceau et al. 1996; Wu et al. 1999). Because of its limited solubility due to the formation of insoluble precipitates, bioavailable levels of $\mathrm{Pb}$ in soils are generally low compared to other heavy metals, thus making it difficult to apply phytoremediation techniques to $\mathrm{Pb}$-contaminated soils. Recent studies demonstrated that the addition of synthetic chelates such as EDTA, HEDTA, and DTPA to contaminated soils can rapidly and dramatically increase $\mathrm{Pb}$ release into the soil solution, thus promoting Pb uptake by plants (Blaylock et al. 1997; Vassil et al. 1998).

Organic acids are important plant root exudates and microbial metabolites in terms of their ability to increase the dissolution of metals from highly insoluble mineral phases in soil, thereby increasing metal mobility in the vicinity of roots and enhancing their 
availability to plants (Naidu and Harter 1998; LópezBucio et al. 2000; Clemens et al. 2002). Several studies have shown the important role that organic acids play at the soil-plant interface. For example, organic acids in pot experiments triggered uranium accumulation in Indian mustard and Chinese cabbage (Huang et al. 1998), and increased chromium accumulation in tomato (Srivastava et al. 1999). Under hydroponic conditions, organic acids furthermore increased the uptake of cadmium by tomato and durum wheat (Senden et al. 1995; Berkelaar and Hale 2003), and of lanthanum by wheat and barley (Wang et al. 2004; Han et al. 2005).

Organic acids play an important physiological role in conferring metal tolerance in that a number of mechanisms involving metal translocation or accumulation are influenced by organic acids. For example, several studies have shown the key role of organic acids in affecting plant tolerance to aluminum (Pellet et al. 1995; Ma et al. 2001). The role of organic acids in mediating the uptake of $\mathrm{Fe}^{3+}$ was ascribed to ferric reductase activity and the presence of cation channels (Schmidt 1999). Compared to other metals, limited information exists on the interactions between organic acids and $\mathrm{Pb}$ at or near the soil-root interface, and the resultant processes of $\mathrm{Pb}$ uptake by plant roots.

Laurie et al. (1991) discussed two possible pathways for metal uptake under the influence of complexes. One pathway involves the dissociation of a metal complex (MeL) in the diffusion layer (solution phase) after which the released free metal ion (Me) may be transported to the root cell across the plasmalemma. Another possible pathway involves the absorption of the metal complex by the root cell membrane; the complex then either undergoes dissociation in the cell membrane, with the free metal ion being transported to the cell while the ligand (L) goes back to the solution phase, or the metal is transported to root cells across the plasmalemma in the form of a complex. Chloride was found to increase $\mathrm{Cd}$ uptake by chard from a resin-buffered solution culture in which activities of $\mathrm{Cd}^{2+}$ were held constant (Smolders and McLaughlin 1996). They suggested that either $\mathrm{CdCl}_{2}^{2-n}$ species were transported across the plasma membrane, or that $\mathrm{Cl}^{1-}$ enhanced the diffusion of $\mathrm{Cd}^{2+}$ through the unstirred liquid layer adjacent to the root surface or through the apoplast to sites of Cd uptake within the root itself. However, solution culture studies in the presence and absence of EDTA indicate that CdEDTA may not be available for plant uptake (Checkai et al. 1987). Berkelaar and Hale (2003) showed that the free ion model (FIM) alone was likely insufficient to predict plant accumulation of metals. Hence, little agreement exists on whether free metal ions or organic ligand-complexes can be more easily taken up by plants.

Recent biophysical studies on the interactions between lead and recombinant proteins and peptides have provided considerable insight into the biological chemistry and molecular toxicology of lead (Godwin 2001). Because lead is non-essential and toxic to plants, it is generally thought that plants are unlikely to have transporters specific for lead. The first example of a plant transporter possibly mediating $\mathrm{Pb}^{2+}$ uptake has been described by Arazi et al. (1999). They revealed a plasma membrane protein $\mathrm{NtCBP} 4$ that conferred $\mathrm{Pb}^{2+}$ hypersensitivity and correlated this with enhanced $\mathrm{Pb}^{2+}$ accumulation. Lead and calcium compete for the same binding sites on proteins that belong to a large family of ion binding compounds. Members of this family include calmodulin, S-100, calretinin, calbindin, and parvalbumin. Lead substitutes for calcium in the activation of calmodulin-dependent phosphodiesterase. CadA and ZntA have been discovered as two $\mathrm{Pb}(\mathrm{II})$ translocating P-type ATPase (Rensing et al. 1998). Still largely unanswered in the question how lead is taken up into plant cells under the influence of organic acids, and what the exact speciation of lead is within plant cells.

The objective of this study was to gain insight into the effects of organic acids on the uptake of $\mathrm{Pb}$ by wheat roots under hydroponic conditions. Relevant mechanisms were investigated by using time- and concentration-dependent $\mathrm{Pb}$ uptake experiments, and various cation channel blockers and the $\mathrm{H}^{+}$-ATPase inhibitor vanadate. Speciation calculations of $\mathrm{Pb}$ in the absence and presence of organic acids and diffuse double layer model were further used to verify the enhanced diffusion of $\mathrm{Pb}$ in the nutrient solution towards wheat roots. We additionally employed such structural sensitive characterization techniques as X-ray absorption near edge spectroscopy (XANES) and extended X-ray absorption fine structure (EXAFS) to investigate the coordination environment of $\mathrm{Pb}$ in wheat roots.

\section{Materials and methods}

\section{Plant cultivation}

Wheat (Triticum aestivum L. cv. JM9158) seeds were obtained from the Chinese Academy of Agricultural Sciences (Beijing, China). Seeds were first surfacesterilized in $3 \%(\mathrm{v} / \mathrm{v}) \mathrm{H}_{2} \mathrm{O}_{2}$ for $30 \mathrm{~min}$, and then thoroughly rinsed with deionized water. After soaking the seeds in $2.8 \mathrm{mM} \mathrm{Ca}\left(\mathrm{NO}_{3}\right)_{2}$ for $4 \mathrm{~h}$, they were al- 
lowed to germinate on moisture filter paper for 4 days in the dark and subsequently transferred to hydroponic solutions containing major nutrients [one-thirdstrength of $1.5 \mathrm{mM} \mathrm{KNO} 3,1 \mathrm{mM} \mathrm{Ca}\left(\mathrm{NO}_{3}\right)_{2}, 0.5 \mathrm{mM}$ $\left.\mathrm{MgSO}_{4}, 0.25 \mathrm{mM}\left(\mathrm{NH}_{4}\right) \mathrm{H}_{2} \mathrm{PO}_{4}\right]$ and micronutrients [full-strength of $11.9 \mu \mathrm{M}$ ethylenediaminetetraacetic acid-iron (EDTA-Fe), $11.5 \mu \mathrm{M} \quad \mathrm{H}_{3} \mathrm{BO}_{3}, 1.25 \mu \mathrm{M}$

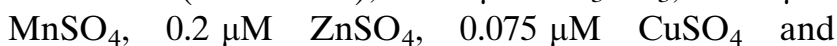
$\left.0.025 \mu \mathrm{M}\left(\mathrm{NH}_{4}\right)_{6} \mathrm{Mo}_{7} \mathrm{O}_{24}\right]$. The solutions were buffered to $\mathrm{pH} 5.8$ with $2 \mathrm{mM}$ Mes-Tris. Plants were grown in a plant growth chamber subject to continuous aeration and with day and night temperature of $22^{\circ} \mathrm{C}(16 \mathrm{~h})$ and $15^{\circ} \mathrm{C}(8 \mathrm{~h})$, respectively. A relative humidity between 50 and $60 \%$ and a photon flux intensity of $300 \mu \mathrm{mol} \mathrm{m}$ ${ }^{2} \mathrm{~s}^{-1}$ were maintained during the entire experimental period. Fresh nutrient solutions were renewed every 3 days. The $\mathrm{Pb}$ treatment solutions contained the same nutrients, but without $\mathrm{NH}_{4} \mathrm{H}_{2} \mathrm{PO}_{4}$ and EDTA-Fe, while $\mathrm{MgSO}_{4}$ was applied at one-tenth strength in order to avoid precipitation.

Effect of molar concentration ratio of organic acids to $\mathrm{Pb}$ on $\mathrm{Pb}$ accumulation

Uniform 22-day-old wheat seedlings were removed from the nutrient solutions, rinsed with deionized water for $2 \mathrm{~min}$, and placed in groups of four in the modified uptake solutions. As control we used an uptake solution containing $20 \mu \mathrm{M} \mathrm{Pb}$ as $\mathrm{Pb}\left(\mathrm{NO}_{3}\right)_{2}$ without the organic acids. Six different molar concentration ratios $(2: 1,5: 1,10: 1,20: 1,50: 1,100: 1)$ of acetic or malic acid to $\mathrm{Pb}$ were employed. Acetic and malic acids were chosen as representative of organic acids since they are ubiquitous in many plant exudates (Cieśliński et al. 1998; Jones 1998). After exposure to amended solutions for $4 \mathrm{~h}$, the seedlings were removed and thoroughly rinsed with deionized water and desorbed. The desorbed roots were next gently blotted, weighed and digested for final determination of $\mathrm{Pb}$. The desorption procedures were conducted for $15 \mathrm{~min}$ in ice-cold $5 \mathrm{mM} \mathrm{CaCl}_{2}$ solutions containing $5 \mathrm{mM}$ Mes-Tris $(\mathrm{pH}$ 6.0) to remove apoplastic $\mathrm{Pb}$ (Hart et al. 1998). These and all subsequent experiments with wheat seedlings were performed in quadruplicate.

Short-term uptake and long-term accumulation of $\mathrm{Pb}$ as affected by organic acids

To study the time-dependency of $\mathrm{Pb}$ uptake, uniform 22-day-old wheat seedlings were transferred from the hydroponic solutions to uptake solutions containing $20 \mu \mathrm{M} \mathrm{Pb}$ with or without $200 \mu \mathrm{M}$ of either acetic or malic acids. The wheat seedlings were analyzed for $\mathrm{Pb}$ content after uptake time periods of 5, 10, 20, 40, 60, 90 and $120 \mathrm{~min}$, and 2, 4, 8, 12, 24 and $48 \mathrm{~h}$. For the shortterm $(0-2 \mathrm{~h})$ uptake experiments, subsamples of the roots were collected followed by desorption for $15 \mathrm{~min}$ in $5 \mathrm{mM}$ ice-cold $\mathrm{CaCl}_{2}$ (5 mM Mes-Tris, $\left.\mathrm{pH} 6.0\right)$, or without desorption prior to $\mathrm{Pb}$ determination. The incubation solutions for the long-term $(>12 \mathrm{~h})$ accumulation experiments were replaced every $12 \mathrm{~h}$. All wheat roots were desorbed and digested for $\mathrm{Pb}$ determination.

Concentration-dependent kinetics of $\mathrm{Pb}$ uptake as affected by organic acids

Three parallel experiments were performed simultaneously to test the effect of external $\mathrm{Pb}$ concentrations on $\mathrm{Pb}$ uptake. Uniform 22-day-old wheat seedlings were for this purpose incubated with fresh nutrient solutions containing various concentrations of $\mathrm{Pb}(0,5$, $10,20,40,60,80,100 \mu \mathrm{M})$. Acetic and malic acids were added separately in two of the experiments at molar concentration ratio of 10:1 (organic acid: $\mathrm{Pb}$ ). After incubation for $20 \mathrm{~min}$, the seedlings were harvested and the roots desorbed. $\mathrm{Pb}$ concentrations of the wheat roots were subsequently determined following acid digestion.

\section{Membrane permeability}

Wheat seedlings were incubated in different treatment solutions for 1-2 days. During this period the incubation solution was replaced every $12 \mathrm{~h}$ with a fresh solution. Treatment solutions (including the control nutrient and uptake solutions) were amended with $20 \mu \mathrm{M} \mathrm{Pb}$ with or without $200 \mu \mathrm{M}$ acetic acid. At the end of the experiments, roots were thoroughly washed twice with $5 \mathrm{mM}$ ice-cold $\mathrm{CaCl}_{2}$ (5 mM Mes-Tris, $\mathrm{pH}$ 6.0) to remove nutrient solution from the apoplast and then blotted on filter paper. Each sample consisting of four seedlings was subsequently introduced into a $25 \mathrm{ml}$ of fresh $0.2 \mathrm{mM} \mathrm{CaCl}{ }_{2}$ solution and incubated for $4 \mathrm{~h}$ in a water bath at $25^{\circ} \mathrm{C}$ with gentle shaking (Andreu et al. 2000). Aliquots of this solution were taken at $1 \mathrm{~h}$ intervals and the $\mathrm{K}^{+}$efflux to the external solution was measured using inductively coupled plasma-atomic emission spectrometry (ICP-AES) (Optima 2000DV, Perkin Elmer Co., Wellesley, MA, USA).

Effects of cation channel blockers on $\mathrm{Pb}$ influx

To better understand the transport pathway of the increased $\mathrm{Pb}$ influx, we next examined the physiologi- 
cal functions of the $\mathrm{Ca}^{2+}$ channel inhibitor of $\mathrm{La}^{3+}$ and the $\mathrm{K}^{+}$channel inhibitor of $\mathrm{Cs}^{+}$. The experiments were carried out again with uniform 22-day-old wheat seedlings, now incubated in nutrient solutions amended with $0.2 \mathrm{mM} \mathrm{La}^{3+}$ or $\mathrm{Cs}^{+}$as $\mathrm{La}\left(\mathrm{NO}_{3}\right)_{3}$ or $\mathrm{CsCl}$, respectively. An unamended nutrient solution was used as the control. $\mathrm{La}\left(\mathrm{NO}_{3}\right)_{3}$ and $\mathrm{CsCl}$ have previously been identified as cation channel blockers by White (1997) and by Essah et al. (2003), who also reported appropriate application concentrations. The $\mathrm{Pb}$ concentrations in our experiments were maintained at $20 \mu \mathrm{M}$. Acetic and malic acids were applied at molar concentration ratio of 10:1 (organic acid: $\mathrm{Pb}$ ). The wheat seedlings were harvested after $4 \mathrm{~h}$ of incubation. Roots were desorbed and acid digested prior to final determination of $\mathrm{Pb}$. As before, all experiments were performed in quadruplicate.

\section{Influence of vanadate on $\mathrm{Pb}$ uptake}

The effect of vanadate on $\mathrm{Pb}$ uptake was analyzed by pre-treating 22-day-old wheat seedlings with $0.1 \mathrm{mM}$ vanadate for $15 \mathrm{~min}$ prior to exposure to $20 \mu \mathrm{M} \mathrm{Pb}$ solution with or without the organic acids. As before, the molar concentration ratio of organic acids to $\mathrm{Pb}$ was again maintained at 10:1. After $4 \mathrm{~h}$ of incubation, wheat roots were harvested, desorbed and acid digested prior to $\mathrm{Pb}$ determination.

\section{Speciation calculations}

The chemical speciation of $\mathrm{Pb}$ in the incubation solutions in the presence and absence of organic acids was predicted using the computer program Visual MINTEQ, version 2.50 (Gustafsson 2006). Full consideration was given in the calculations to mole balances, relevant thermodynamic equilibrium constants and ionic strengths.

\section{X-ray absorption spectroscopic studies}

We additionally performed X-ray absorption spectroscopic (XAS) studies to obtain direct information on the coordination chemistry of $\mathrm{Pb}$ in the 22-day-old wheat seedlings, which had been transferred into $20 \mu \mathrm{M} \mathrm{Pb}$ culture solutions containing $200 \mu \mathrm{M}$ acetic acid. X-ray absorption spectroscopy is an elementspecific and bulk-sensitive method. The seedlings for this study were harvested after 2 days of uptake. The fresh wheat roots (desorbed and undesorbed) were ground in an agate mortar and pestle under the protection of liquid $\mathrm{N}_{2}$. The fine root powders were next pressed into pellets (diameter of $0.84 \mathrm{~cm}$ and thickness of $0.15 \mathrm{~cm}$ ) for the XAS experiments. Instrumental conditions for measurement of the XAS spectra at the $\mathrm{Pb} \mathrm{L}_{3}$-edge are described in detail elsewhere (Qin et al. 2006).

Data processing and analyses were performed with WinXAS 2.1 following standard procedures. The energy $\mathrm{E}_{0}(13,035 \mathrm{eV})$ was defined as the inflection point of the absorption edge for the transform from energy to $k$ space. The pre-edge absorption background was fitted and subtracted by using Victoreen functions. The post-edge absorption backgrounds were fitted with a spline function and subtracted from the absorption spectra. The EXAFS functions were normalized using the absorption edge jump, and next Fourier transformed into $\mathrm{R}$-space with $k^{2}$-weighting over the range from 2.2 to $10.0 \AA$. We chose $k=2$ weighting for $\mathrm{Pb}$ since a higher $k$ value decreased the signal-to-noise ratio. The fits were performed in $\mathrm{R}$-space with the coordination number $(\mathrm{N})$ fixed, while the interatomic distance $(\mathrm{R})$, the energy shift $\left(\mathrm{E}_{0}\right)$, and the DebyeWaller factor $\left(\sigma^{2}\right)$ were allowed to float. The amplitude and phase shift parameters were obtained from theoretical calculations with $\mathrm{Pb}\left(\mathrm{CH}_{3} \mathrm{COO}\right)_{2} \cdot 3 \mathrm{H}_{2} \mathrm{O}$ as reference using the FEFF 8.0 code (Rehr et al. 1992).

\section{Determination of $\mathrm{Pb}$}

The $\mathrm{Pb}$ contents of the various plant samples were analyzed by digesting them with 3-ml concentrated $\mathrm{HNO}_{3}-\mathrm{HClO}_{4}(2: 1$, v:v) solutions under high pressure conditions (Zhang and Shan 1997). Pb concentrations in the samples were determined using ICP-AES (Optima 2000 DV, Perkin Elmer Co.). Certified reference materials (peach leaves, GBW 08501, PR China) were used to ensure the quality of analyses. Good agreement was obtained between the data obtained with our method and the certified values.

Statistical analysis of data

The data were analyzed using the Microcal Origin 7.0 (Microcal Software, Northampton, MA, USA) and SPSS 12.0 for windows (SPSS, Chicago, IL, USA) software packages.

\section{Results}

Effect of molar concentration ratio of organic acids to $\mathrm{Pb}$ on the accumulation of $\mathrm{Pb}$

Figure 1 shows the effects of acetic and malic acid on the accumulation of $\mathrm{Pb}$ by the wheat roots as a function 


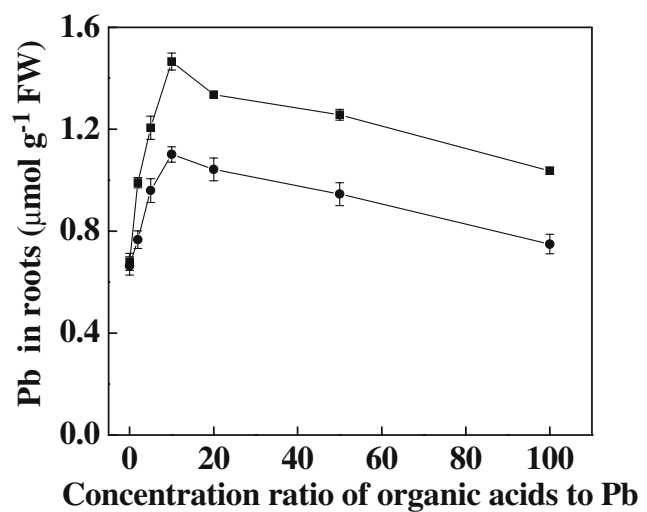

Fig. 1 Effect of molar concentration ratio (organic acids: $\mathrm{Pb}$ ) for acetic acid (filled square) and malic acid (filled circle) on the uptake of $\mathrm{Pb}$ by wheat roots (Triticum aestivum L.). Values are means $\pm 1 \mathrm{SE}$ of four replicates. The data at a concentration ratio of 0 are for the controls (i.e., for nutrient solutions containing $\mathrm{Pb}$ but no organic acids)

of the molar concentration ratio of organic acid to $\mathrm{Pb}$. While acetic and malic acids qualitatively showed similar trends in terms of enhancing $\mathrm{Pb}$ accumulation, acetic acid had a much greater effect than malic acid. The maximum concentrations of $\mathrm{Pb}$ in the roots occurred at a concentration ratio of $10: 1$. The $\mathrm{Pb}$ content of the desorbed wheat roots at that ratio, after $4 \mathrm{~h}$ of exposure, increased by 116 and $75 \%$ for acetic and malic acid, respectively, relative to the control $(P<0.05)$. The $\mathrm{Pb}$ contents of the roots decreased with a further increase in the organic acid to $\mathrm{Pb}$ ratio. For this reason we used a molar concentration ratio of 10:1 (organic acid: $\mathrm{Pb}$ ) in most or all subsequent experiments.

Short-term uptake and long-term accumulation of $\mathrm{Pb}$ as affected by organic acids

Compared to seedlings grown in the control solution, $\mathrm{Pb}$ concentrations of wheat roots grown in nutrients solutions with the organic acids were found to be consistently greater for both the short- and long-term experiments. Figure $2 \mathrm{a}, \mathrm{b}$ show the short-term $(0$ $120 \mathrm{~min}) \mathrm{Pb}$ uptake by wheat roots without and with $\mathrm{CaCl}_{2}$ desorption, respectively. The uptake patterns were similar for the control and the organic acid treatment solutions. Acetic and malic acid both noticeably enhanced the short-term uptake of $\mathrm{Pb}$. For wheat roots without $\mathrm{CaCl}_{2}$ desorption, $\mathrm{Pb}$ uptake was biphasic in that a relatively fast initial phase was followed by a much slower and more linear second phase (Fig. 2a). The initial rapid phase (i.e., during the first $20 \mathrm{~min}$ ) was presumably due to diffusion of $\mathrm{Pb}$ into free space and binding to root cell walls. The slower
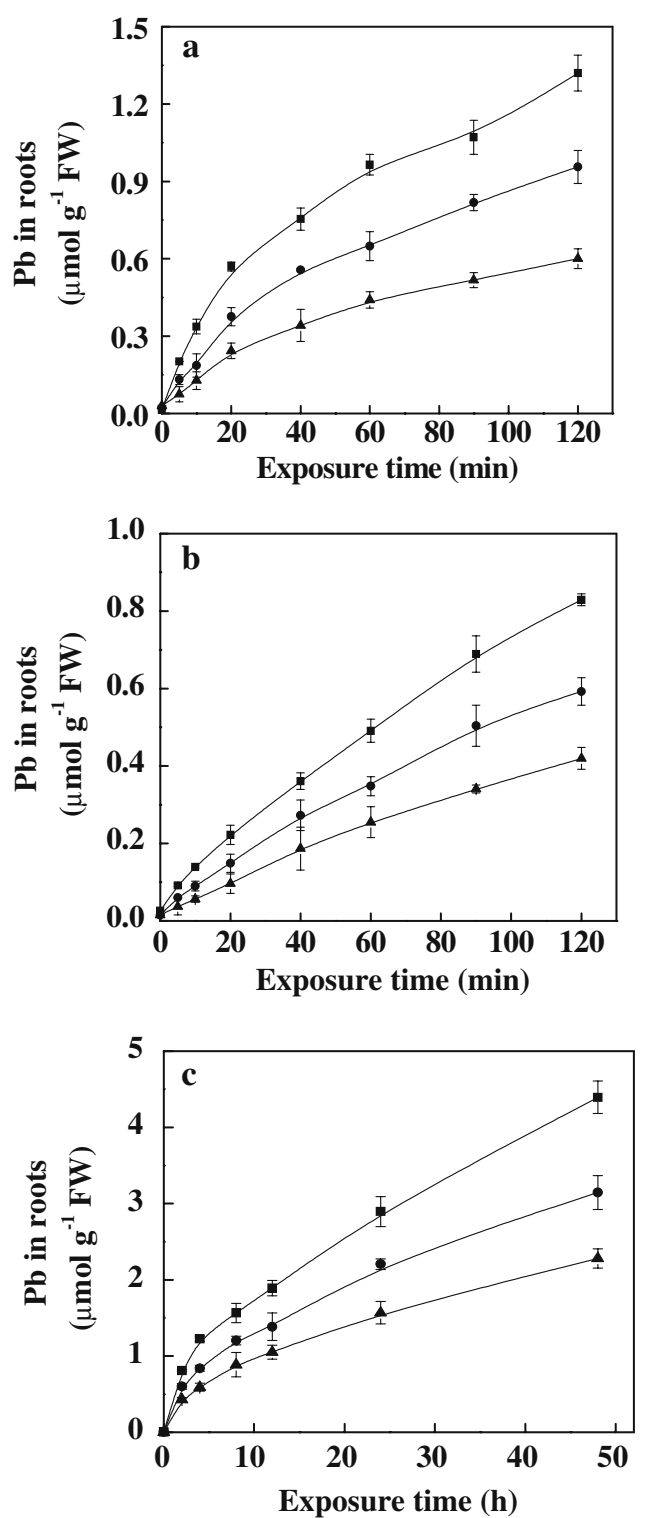

Fig. 2 Time-dependent uptake of $\mathrm{Pb}$ by wheat roots (Triticum aestivum $\mathrm{L}$.) from solutions containing $\mathrm{Pb}$ but no organic acids (filled triangle), $\mathrm{Pb}$ and malic acid (filled circle), and $\mathrm{Pb}$ and acetic acid (filled square). Acetic and malic acids were applied at a molar concentration ratio of 10:1 (organic acid: $\mathrm{Pb}$ ). Values are means $\pm 1 \mathrm{SE}$ of four replicates. Results are for the short-time $(\leq 2 \mathrm{~h})$ uptake experiments without a and with b desorption, and for the long-time (up to $48 \mathrm{~h}$ ) accumulation experiments with desorption (c)

linear phase of $\mathrm{Pb}$ uptake between 20 and 120 min may correspond to transport across the plasma membrane. The second phase could also be due to slower diffusion into the apoplast and external binding to cells in the cortex.

Our results for the three uptake experiments with $\mathrm{CaCl}_{2}$ desorption resemble previous findings by Lasat et al. (1996). The linear nature of $\mathrm{Pb}$ uptake by de- 
sorbed wheat roots suggests that unidirectional $\mathrm{Pb}$ influx into the root symplast occurred for at least $120 \mathrm{~min}$ (Fig. 2b). The curves intercepted the axis slightly above the origin, thus indicating the presence of relatively small amounts of rapidly bound $\mathrm{Pb}$ that were not removed during the 15 -min desorption process. This undesorbed fraction probably consisted of $\mathrm{Pb}$ bound to reactive sites within the apoplast. After $2 \mathrm{~h}$ of exposure, $\mathrm{Pb}$ concentrations in the desorbed wheat roots of the acetic and malic acid treatments were, respectively, 2.1 and 1.5 times greater than that of the control $(P<0.05)$.

Figure $2 \mathrm{c}$ shows the long-term $\mathrm{Pb}$ accumulation by wheat roots. After about $4 \mathrm{~h}$ of rapid uptake, $\mathrm{Pb}$ continued to be accumulated for at least $48 \mathrm{~h}$, but at a slower rate. The accumulation did not reach a final value after $48 \mathrm{~h}$ since the wheat seedlings were still growing. Compared with $\mathrm{Pb}$ accumulation from the control solution, the $\mathrm{Pb}$ content of desorbed wheat roots after $48 \mathrm{~h}$ of exposure was increased by 93 and $40 \%$ for acetic and malic acid, respectively (Fig. 2c, $P<0.05)$.

Concentration-dependent $\mathrm{Pb}$ uptake as affected by acetic and malic acids

Data from the relatively short uptake period $(<20 \mathrm{~min})$ were used to investigate uptake while minimizing the possibility of $\mathrm{Pb}$ efflux across the plasma membrane back into the external solution. Figure 3 a shows that the concentration-dependent $\mathrm{Pb}$ uptake data for the wheat seedlings are characterized by smooth, nonsaturating curves that become linear at $\mathrm{Pb}$ concentration greater than about $20 \mu \mathrm{M}$. The organic acids increased $\mathrm{Pb}$ uptake over the entire range of applied $\mathrm{Pb}$ in the uptake solutions. The uptake kinetics of $\mathrm{Pb}$ in the presence and absence of acetic and malic acids were biphasic and could be described well with a modified Michaelis-Menten type equation involving linear and saturable components as follows (see also Fig. 3b):

$V=a C+\frac{V_{\max } C}{K_{\mathrm{m}}+C}$

where $V$ is the uptake rate, $C$ is the $\mathrm{Pb}$ concentration in the nutrient solution, $a$ is parameter characterizing the linear part of the uptake rate, and $V_{\max }$ and $K_{\mathrm{m}}$ are the maximum uptake rate and Michaelis-Menten rate constant of the saturable (second) component of (1). The $r^{2}$ values for the acetic and malic acid treatments and for the control were 0.993, 0.996 and 0.998, respectively. The linear component presumably represents cell-wall-bound $\mathrm{Pb}$ remaining after desorption,
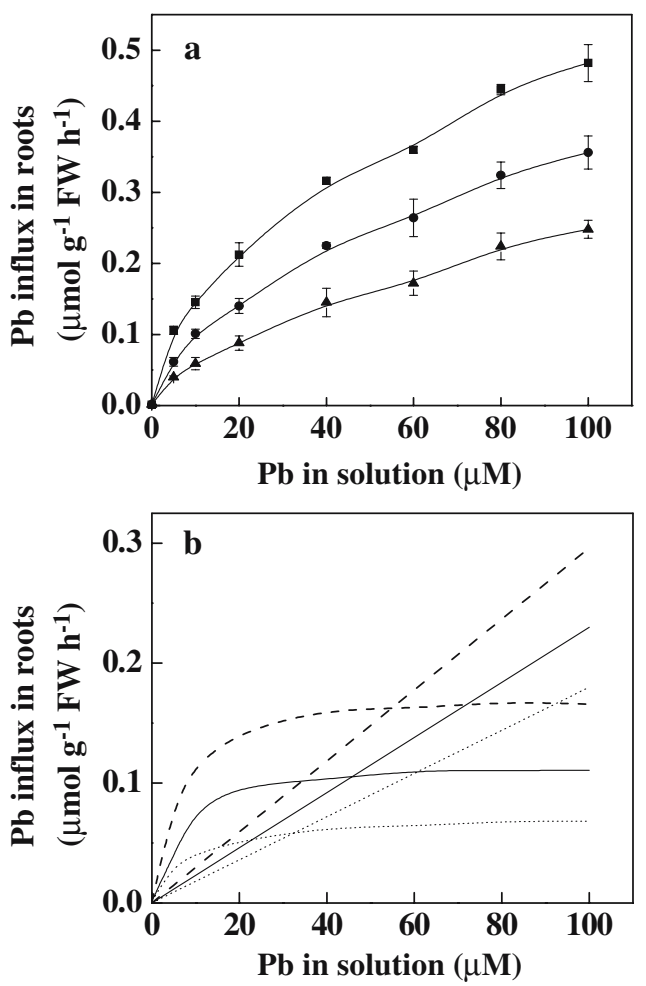

Fig. 3 Concentration-dependent uptake kinetics of $\mathrm{Pb}$ by wheat roots (Triticum aestivum L.) from solutions containing $\mathrm{Pb}$ but no organic acids (filled triangle), $\mathrm{Pb}$ and malic acid (filled circle), and $\mathrm{Pb}$ and acetic acid (filled square). Acetic and malic acids were applied at a molar concentration ratio of 10:1 (organic acid:Pb). a Measured overall kinetic curves for $\mathrm{Pb}$ uptake influx; values are means \pm 1 SE of four replicates; $\mathbf{b}$ Deconvolution of the overall kinetic curves into linear and saturable components according to Eq. 1. The uptake curves are for $\mathrm{Pb}$ (dotted line), $\mathrm{Pb}$ and malic acid (solid line), and $\mathrm{Pb}$ and acetic acid (dashed line)

while the saturable component represents true uptake across the plasma membrane. Values of $V_{\max }$ for the acetic and malic acid treatments were found to be 179.2 and $120.5 \mathrm{nmol} \mathrm{g}^{-1} \mathrm{fw} \mathrm{h}^{-1}$, respectively, which were 2.45 and 1.63 times that of the control, respectively. The corresponding $K_{\mathrm{m}}$ values were within the same order of magnitude $(5.5,3.7$ and $2.2 \mu \mathrm{M}$, respectively). These results indicate that acetic and malic acids significantly enhanced $\mathrm{Pb}$ influx into the root symplasm.

Membrane integrity

In order to test whether organic acids at high concentrations and $\mathrm{Pb}$ exert toxic effect on the membrane integrity of wheat roots, the membrane integrity was examined by measuring the $\mathrm{K}^{+}$efflux to the external solution. Results indicate that the $\mathrm{K}^{+}$concentration of the external solution remained almost the same when the plants were exposed to the nutrient solutions alone, 
or to the nutrient solutions with $200 \mu \mathrm{M}$ acetic acid or with $20 \mu \mathrm{M} \mathrm{Pb}$ or with $200 \mu \mathrm{M}$ acetic acid and $20 \mu \mathrm{M}$ $\mathrm{Pb}$ together, over culture time intervals of 1-2 days on the base of fresh wheat root weight (Fig. 4). There were no significant differences between the $\mathrm{K}^{+}$contents of the external solution for the different plant culture conditions. These results suggest that plasma membrane integrity was not adversely affected by the application of $200 \mu \mathrm{M}$ acetic acid or $20 \mu \mathrm{M} \mathrm{Pb}$. We hence conclude that the observed $\mathrm{Pb}$ uptake enhancement in wheat roots in the presence of organic acids was not due to toxic action of either $\mathrm{Pb}$ or the organic acids.

Effects of cation channels blockers and vanadate on $\mathrm{Pb}$ uptake rate

Figure 5 shows the effects of the $\mathrm{Ca}^{2+}$ channel inhibitor of $\mathrm{La}^{3+}$, the $\mathrm{K}^{+}$channel inhibitor of $\mathrm{Cs}^{+}$, as well as vanadate on $\mathrm{Pb}$ uptake. Results indicate that $\mathrm{La}^{3+}$ and $\mathrm{Cs}^{+}$significantly inhibited the $\mathrm{Pb}$ influx $(P<0.05)$. If we designate the $\mathrm{Pb}$ contents of wheat roots with no organic acid, and with acetic and malic acids, as the control values, $\mathrm{La}^{3+}$ decreased the $\mathrm{Pb}$ contents of the wheat roots by 74,72 and $71 \%$, respectively. Analogously, $\mathrm{Cs}^{+}$decreased the $\mathrm{Pb}$ contents by 62,59 and $57 \%$, respectively. Pre-treatment of wheat roots by vanadate, a $\mathrm{H}^{+}$-ATPase inhibitor, for $15 \mathrm{~min}$, caused the $\mathrm{Pb}$ contents of wheat roots to decrease by 55,37 , and $51 \%$, respectively (Fig. 5, $P<0.05$ ).

We note here that, except for the ion channels (White 1997), two other possible mechanisms involved in the passage of ions through the plasma membranes of cortical and xylem parenchyma are ion pumping and the presence of carriers.

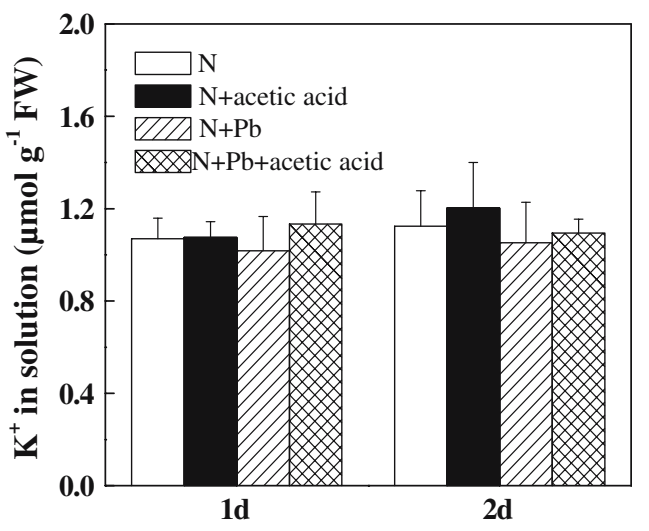

Fig. 4 Potassium concentration of the external solution after treatment for 1 and $2 \mathrm{~d}$ with and without the presence of $200 \mu \mathrm{M}$ acetic acid and $20 \mu \mathrm{M} \mathrm{Pb}$. $\mathrm{N}$ represents the nutrient solution. Values are means $\pm 1 \mathrm{SE}$ of four replicates

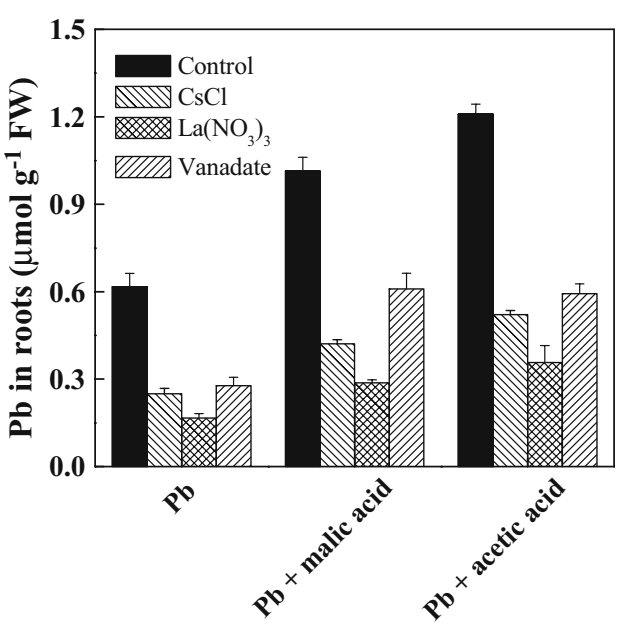

Fig. 5 Effects of cation channel inhibitors and vanadate on the influx of $\mathrm{Pb}$ in wheat (Triticum aestivum L.) roots as influenced by organic acids. Values are means $\pm 1 \mathrm{SE}$ of four replicates

Speciation of $\mathrm{Pb}$ in the absence and presence of organic acids

The speciation of $\mathrm{Pb}$ in the absence and presence of acetic and malic acids as computed with the Visual MINTEQ program is shown in Table 1 . The results indicate that free $\mathrm{Pb}^{2+}$ dominated the nutrient and uptake solutions, and that organic acids decreased the free $\mathrm{Pb}^{2+}$ concentration as compared to the control. Malic acid decreased free $\mathrm{Pb}^{2+}$ concentration more than acetic acid. Moreover, as the molar concentration ratio of organic acids to $\mathrm{Pb}$ increased from 2:1 to 100:1, the percentage of free $\mathrm{Pb}^{2+}$ decreased from 94.6 to $61.7 \%$ for acetic acid and from 91.5 to $31.7 \%$ for malic acid. The $\mathrm{Pb}$-acetate and $\mathrm{Pb}$-malate contents were very low (only 5.19 and $18.5 \%$, respectively) when the molar concentration ratio of acetic and malic acids to $\mathrm{Pb}$ was set at 10:1. However, the $\mathrm{Pb}$-acetate and $\mathrm{Pb}$-malate contents increased when the ratio of organic acids to $\mathrm{Pb}$ increased from 2:1 to 100:1.

Effect of acetic and malic acids on the thickness of unstirred layer of $\mathrm{Pb}$ adjacent to roots

Plant roots generally have a negatively charged surface due to the presence of $\mathrm{O}^{-}$and $\mathrm{COO}^{-}$groups, which leads to the formation of an unstirred layer adjacent to the root surface. The unstirred layer of a nutrient solution contains an excess of ions called counterions (e.g., $i^{+}$in Fig. 6) that carry charge equal in magnitude and opposite in sign to that exhibited by the root surface. The thickness of the unstirred layer varies inversely with the ionic strength of the nutrient solution. The characteristic thickness is given by $0.28 \times I^{-0.5} \mathrm{~nm}$, 
Table $1 \mathrm{~Pb}$ chemical speciation $(\%$ of total $\mathrm{Pb}$ ) of nutrient solutions in the presence and absence of organic acids as calculated with Visual MINTEQ using our initial solution composition

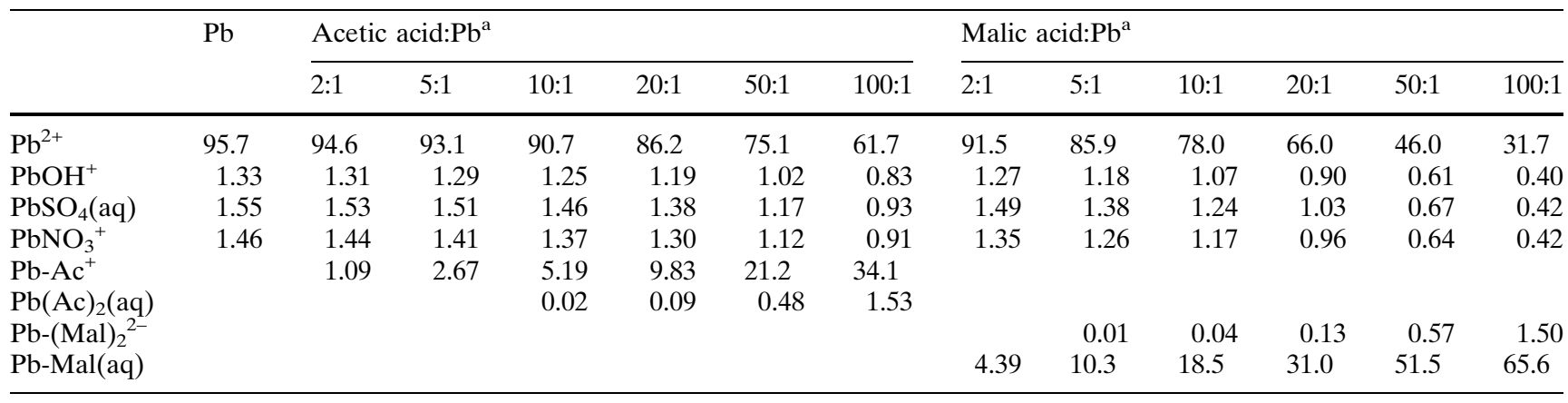

Results are for a pH of 5.8 and a temperature of $25^{\circ} \mathrm{C}$. Pb was maintained at $20 \mu \mathrm{M}$

Ac acetic acid, Mal malic acid

${ }^{a}$ Different molar concentration ratio of organic acids to $\mathrm{Pb}$

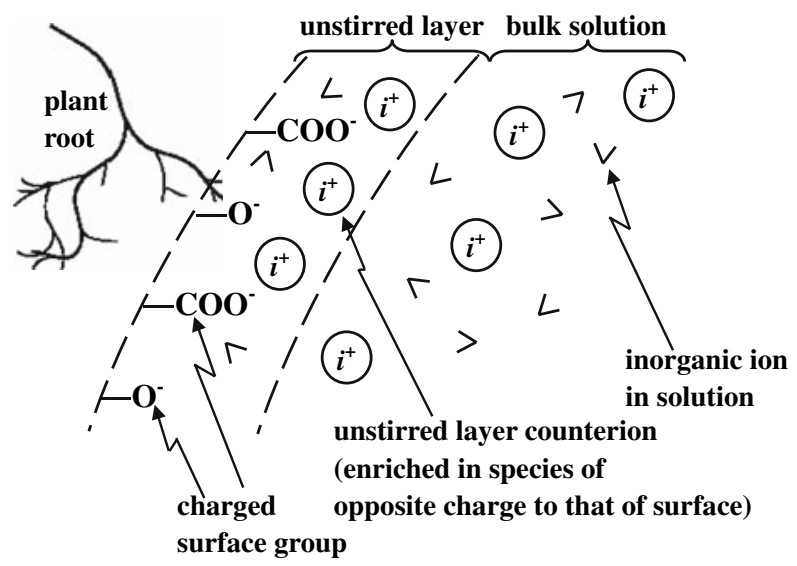

Fig. 6 Schematic showing how a negatively charged root surface attracts cations, including $\mathrm{Pb}^{2+}$ (e.g., $\left.i^{+}\right)$, in the unstirred layer of a nutrient solution

where $I$ is the nutrient solution's ionic strength in molar units (e.g., Schwarzenbach et al. 2003). The thickness of the unstirred layer was $6.56 \mathrm{~nm}$ for the nutrient solution without $\mathrm{Pb}$ and without organic acids. When the molar concentration ratio of acetic or malic acid to $\mathrm{Pb}$ increased from 2:1 to 10:1, the thickness of the unstirred layer decreased from 6.42 to $6.30 \mathrm{~nm}$ for acetic acid and from 6.16 to $5.92 \mathrm{~nm}$ for malic acid. These results suggest that the unstirred layer was thinner in the presence of organic acids, thus creating a situation in which the counterions (including $\mathrm{Pb}^{2+}$ ) are more readily absorbed or taken up by wheat roots. This finding is consistent with the observed enhanced uptake of $\mathrm{Pb}$ by wheat (Fig. 1). However, when the molar concentration ratio of organic acids to $\mathrm{Pb}$ further increased and the thickness of the unstirred layer further decreased, the uptake of $\mathrm{Pb}$ by wheat roots eventually decreased. We postulate that this is due to the adverse effect of higher organic acid concentrations on the plasma membrane.

Coordination environment of $\mathrm{Pb}$ in wheat roots

Normalized XANES spectra of $\mathrm{Pb}$ for the root samples and model compounds are shown in Fig. 7. A sharp peak occurred in $\mathrm{Pb} \mathrm{L}_{3}$-XANES, which was caused primarily by $2 p$ to $5 \mathrm{~d}$ electronic transition of $\mathrm{Pb}$. Better spectral agreement was obtained between root samples (inflection at $13049.3 \mathrm{eV}$ ) and $\mathrm{Pb}\left(\mathrm{CH}_{3} \mathrm{COO}\right)_{2} \cdot 3 \mathrm{H}_{2} \mathrm{O}$ (inflection at $13048.5 \mathrm{eV}$ ). For $\mathrm{Pb}\left(\mathrm{NO}_{3}\right)_{2}$ the peak shifted to a lower energy at $13042.3 \mathrm{eV}$ and showed greater intensity. The XANES spectra of the root samples also exhibited a clear maximum at $13085.3 \mathrm{eV}$. Similar maxima were observed for $\mathrm{Pb}\left(\mathrm{CH}_{3} \mathrm{COO}\right)_{2}$. $3 \mathrm{H}_{2} \mathrm{O}$, but to a lesser extent, while the $\mathrm{Pb}\left(\mathrm{NO}_{3}\right)_{2}$ and $\beta$-PbO spectra did not show such features. These distinct differences in the XANES spectra arise from different local geometries and occupancies of the final electronic states. The similarities in the XANES structure for root samples and $\mathrm{Pb}\left(\mathrm{CH}_{3} \mathrm{COO}\right)_{2} \cdot 3 \mathrm{H}_{2} \mathrm{O}$ demonstrate that their local atomic configurations surrounding the central $\mathrm{Pb}$ atoms are similar. In $\mathrm{Pb}\left(\mathrm{CH}_{3} \mathrm{COO}\right)_{2} \cdot 3 \mathrm{H}_{2} \mathrm{O}, \quad \mathrm{Pb}$ is bound with carboxyl functional groups, which indicates that $\mathrm{Pb}$ in roots are coordinated via similar chemical environments. Similar results were obtained by Sarret et al. (1998).

The $k^{2}$-weighted EXAFS spectra and Fourier transforms for the wheat root samples and reference compounds are presented in Fig. 8a, b. Compared to the undesorbed roots, the $k^{2}$-weighted EXAFS spectrum for the desorbed roots showed more noise above $6.2 \AA^{-1}$ due to lower $\mathrm{Pb}$ contents in the desorbed roots. The first two oscillations for the root samples at 3.6 and $5.5 \AA^{-1}$ showed a fingerprint feature, and are 


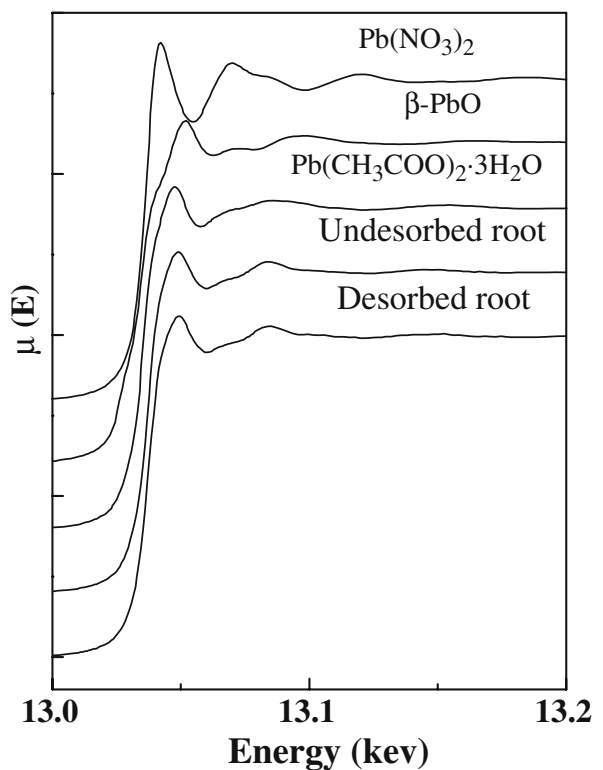

Fig. 7 Normalized $\mathrm{Pb} \mathrm{L}_{3}$-edge XANES for desorbed and undesorbed wheat (Triticum aestivum L.) roots and model compounds

similar to those for $\mathrm{Pb}\left(\mathrm{CH}_{3} \mathrm{COO}\right)_{2} \cdot 3 \mathrm{H}_{2} \mathrm{O}$. The Fourier transforms reflect a relative radial distribution function of lead(II) with neighboring atoms located in the local coordination shells. The dominant peak at $1.62 \AA$ arose from the first shell of $\mathrm{Pb}-\mathrm{O}$. However, this peak for model compound $\mathrm{Pb}\left(\mathrm{NO}_{3}\right)_{2}$ was shifted $0.3 \AA$ higher than the others. The second weak peak around $3.3 \AA$ for the root samples probably arose from the second-shell due to metal-metal bonding. For $\mathrm{Pb}\left(\mathrm{CH}_{3} \mathrm{COO}\right)_{2} \cdot 3 \mathrm{H}_{2} \mathrm{O}$ the second peak may be due to the effect of $\mathrm{Pb}-\mathrm{Pb}$ and/or $\mathrm{Pb}-\mathrm{C}$ bonds. In addition, a second weak peak around $3.7 \AA$ for $\mathrm{Pb}\left(\mathrm{NO}_{3}\right)_{2}$ was due to the second-shell of $\mathrm{Pb}-\mathrm{N}$. The similarities between the spectra of the root samples and $\mathrm{Pb}\left(\mathrm{CH}_{3} \mathrm{COO}\right)_{2}$. $3 \mathrm{H}_{2} \mathrm{O}$ further support the binding of lead(II) to wheat roots through a similar mechanism, i.e., $\mathrm{Pb}$ was most likely coordinated to oxygen atoms via carboxylic groups.

The fitted results are listed in Table 2 for the first shell. The data indicate that the nearest-neighbor distance of the $\mathrm{Pb}-\mathrm{O}$ bond in wheat roots is similar to those for $\mathrm{Pb}\left(\mathrm{CH}_{3} \mathrm{COO}\right)_{2} \cdot 3 \mathrm{H}_{2} \mathrm{O}$ but deviates from those of $\mathrm{Pb}\left(\mathrm{NO}_{3}\right)_{2}$. No XAS study was carried out for wheat roots treated with malic acid since we were unable to obtain lead malate reference compounds.

\section{Discussion}

Organic acids may influence metal solubility and uptake through their indirect effects on microbial activity, rhizosphere physico-chemical properties, and root growth dynamics, as well as more directly through acidification, complexation, precipitation and oxidation-reduction reactions in the rhizosphere (Cieśliński et al. 1998). Still, relatively little information exists on the effects of organic acids on the uptake of $\mathrm{Pb}$ by plants. The results of our experiments clearly demonstrate that organic acids enhance $\mathrm{Pb}$ uptake by wheat roots (Figs. 1,2). The significant greater $V_{\max }$ values in the presence of acetic and malic acids reflect the enhanced net influx of $\mathrm{Pb}$ into symplasm.

In the uptake experiments, binding to the cell wall could have confounded the estimation of $\mathrm{Pb}$ transport into the cytosol. In principle, extracellular absorption must not be considered true uptake by plants.
Fig. $8 \mathrm{~Pb} \mathrm{~L}_{3}$-edge EXAFS data (a) and Fourier transforms of the EXAFS data (b) along with fits to the data. The solid line represents the data, while the dotted line was fitted to the data. Results of the data analysis are presented in Table 2
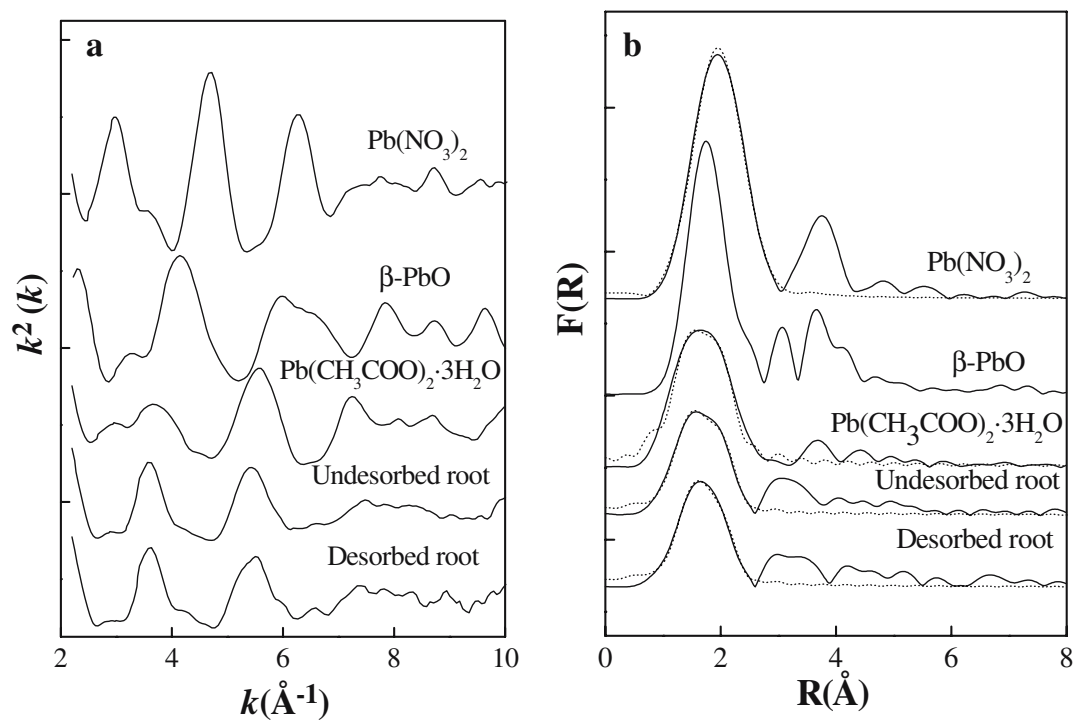
Table 2 Results of fits to the EXAFS data

Errors of approximately $20 \%$ in the coordination number and $0.01 \AA$ in the bond distance

\begin{tabular}{|c|c|c|c|c|c|c|}
\hline \multirow[t]{2}{*}{ Samples } & \multicolumn{3}{|c|}{ First $\mathrm{Pb}-\mathrm{O}$ shell } & \multicolumn{3}{|c|}{ Second $\mathrm{Pb}-\mathrm{O}$ shell } \\
\hline & $\mathrm{N}$ & $R(\AA)$ & $\sigma^{2}\left(\AA^{2}\right)$ & $\mathrm{N}$ & $R(\AA)$ & $\sigma^{2}\left(\AA^{2}\right)$ \\
\hline Undesorbed roots & 4.13 & 2.36 & 0.008 & & & \\
\hline Desorbed roots & 4.02 & 2.26 & 0.011 & & & \\
\hline $\mathrm{Pb}\left(\mathrm{CH}_{3} \mathrm{COO}\right)_{2} \cdot 3 \mathrm{H}_{2} \mathrm{O}$ & 4 & 2.30 & 0.006 & 4 & 2.39 & 0.007 \\
\hline $\mathrm{Pb}\left(\mathrm{NO}_{3}\right)_{2}$ & 6 & 2.63 & 0.002 & 6 & 2.72 & 0.008 \\
\hline
\end{tabular}

Therefore, removal of $\mathrm{Pb}$ from the root surface is essential for accurate measurement of uptake of metals by plants. Desorbed $\mathrm{Pb}$ could have originated from the cell walls and/or from the cytosol via efflux across the plasma membrane back into the external solution. In our experiments, desorption was performed in an icecold water bath. Under such conditions the active $\mathrm{Pb}$ efflux from cytoplasm is presumably inhibited. Based on our experimental results we conclude that most of the desorbed $\mathrm{Pb}$ originated from the root cell walls.

$\mathrm{Pb}$ has been found to significantly inhibit voltagegated $\mathrm{Ca}^{2+}$ channel activity in the plasma membrane of wheat roots (Huang and Cunningham 1996). The inhibition of Ca-channel activity by $\mathrm{Pb}^{2+}$ could result either from competitive transport of $\mathrm{Pb}^{2+}$ through $\mathrm{Ca}-$ channel or from its blockage by $\mathrm{Pb}$. While monitoring $\mathrm{Pb}$ entry into isolated cells, Tomsig and Suszkiw (1991) observed permeation of $\mathrm{Pb}$ through $\mathrm{Ca}$-channels. In maize and wheat plasma membrane vesicles the $\mathrm{Ca}^{2+}$ channel is very sensitive to $\mathrm{La}^{3+}$ (Tyerman and Skerrett 1999). Bregante et al. (1997) reported that $1 \mathrm{mM}$ $\mathrm{Cs}^{+}$was able to block in a very fast and voltagedependent manner up to $96 \%$ of the potassium current in protoplasts of maize roots. Our results suggest that $\mathrm{La}^{3+}$ and $\mathrm{Cs}^{+}$significantly inhibit the uptake of $\mathrm{Pb}$ by wheat roots (Fig. 5). It is generally recognized that $\mathrm{Cs}^{+}$ is a $\mathrm{K}^{+}$channel blocker, while not affecting any $\mathrm{Ca}^{2+}$ channels. $\mathrm{La}^{3+}$ is a broad range $\mathrm{Ca}^{2+}$ channel blocker, but also blocks non-selective cation channels, anion channels and the general metabolism. Interestingly, $\mathrm{Pb}^{2+}$ can bind to $\mathrm{Ca}^{2+}$-binding sites in regulatory proteins such as calmodulin. Recently, the tobacco plasma membrane protein $N t C B P 4$ and the Arabidopsis gene $C N G C 1$ were reported to be components of a transport pathway responsible for $\mathrm{Pb}^{2+}$ entry into plant cells (Sunkar et al. 2000). The involvement of CNGC1 and $C N G C 2$ in the transport of potassium has been reported also (Leng et al. 1999). These results support our evidence that the uptake of $\mathrm{Pb}^{2+}$ was mediated at least in part by $\mathrm{K}^{+}$and $\mathrm{Ca}^{2+}$ channels.

Uptake of cationic solutes is likely to be driven largely also by the negative membrane potential across the plasma membrane, which is generated in part by metabolically dependent processes such as proton extrusion via the plasma membrane $\mathrm{H}^{+}$-ATPase
(Kochian 1991). The pmf generated by plasma membrane $\mathrm{H}^{+}$-pumping ATPase powers transport through a variety of carriers; it also influences ion channel activity through its impact on $V_{\max }$. The plasma membrane $\mathrm{H}^{+}$-ATPase is a P-type ATPase. All P-type ATPase membranes are inhibited by orthovanadate $\left(\mathrm{H}_{2} \mathrm{VO}_{4}^{-}\right)$. Pre-treatment of wheat roots by vanadate significantly inhibited $\mathrm{Pb}$ uptake in our study (Fig. 5), thus suggesting that the enhanced $\mathrm{Pb}$ uptake into the cytosol of wheat was dependent upon physiological functions of the plasma membrane P-type ATPase.

The above discussion on the mechanisms of enhanced uptake of $\mathrm{Pb}$ in the presence of organic acids focuses on mostly plant-physiological aspects of the uptake problem. Interestingly, the mechanisms can also be discussed from a solution chemistry perspective. Table 1 shows the speciation of $\mathrm{Pb}$ in the nutrient and uptake solutions as estimated with Visual MINTEQ, version 2.50. Our results suggest that free $\mathrm{Pb}^{2+}$ was the dominant species, even in the presence of organic acids. In view of the size and polarity of intact $\mathrm{Pb}$ (II)-organic ligand complexes, absorption of these complexes is very unlikely. Also, synthetic chelates cannot slip through the plasma membrane since they are too large and too polar to move through the plasmalemma lipid bilayer (Berne and Levy 1998). However, it seems possible that diffusion of $\mathrm{Pb}$-acetate or $\mathrm{Pb}$-malate complexes was more rapid than free $\mathrm{Pb}^{2+}$ because of the high charge density of $\mathrm{Pb}^{2+}$, thus facilitating these complexes to move more rapidly towards the roots. Once these chelates reach the root surface, the surfaces will promote their dissociation into free $\mathrm{Pb}^{2+}$, which are then more readily absorbed or taken up by the roots.

The reason for acetic and malic acids exert different enhancement effects on the uptake of $\mathrm{Pb}$ may be explained by their different chelating capabilities. The stability constants of complexes formed between $\mathrm{Pb}$ and acetic acid are less than those between $\mathrm{Pb}$ and malic acid, which is contrary to the order of the enhancement effects obtained in our experiments. It is apparent that the lower the stability constants of the $\mathrm{Pb}(\mathrm{II})$-organic ligand complexes, the greater the enhancement effect. This means that $\mathrm{Pb}(\mathrm{II})$-organic ligand complexes are more easily dissociated by wheat 
roots, leading to more uptake of dissociated $\mathrm{Pb}$ ions by the wheat roots.

Negatively charged plant root surface promote the development of an adjacent unstirred layer, and hence relatively high $\mathrm{Pb}^{2+}$ concentration gradient near the roots. According to Kochian et al. (1989), diffusive gradients in the unstirred layer around the roots or in the apoplast can occur and influence the uptake rate of elements, even in well-stirred solutions. Our results suggest that the unstirred layer was effectively thinner in the presence of organic acids, thus allowing $\mathrm{Pb}^{2+}$ to be more readily absorbed or taken up by roots. This finding supports the enhanced uptake of $\mathrm{Pb}$ as shown in Fig. 1.

Lead can be tetravalent or divalent. Divalent lead possesses a $6 \mathrm{~s}^{2}$ outer shell electronic configuration. The two lone pair electrons are often stereochemically active and induce a strong deformation of divalent lead polyhedron. Another source of complexity of the coordination chemistry of lead comes from the high variability of its coordination number. All possible coordination values (between 3 and 12) have been reported in the literature. Our EXAFS data indicate that one $\mathrm{Pb}$ (II) atom was coordinated to four oxygen atoms and that the coordination environment of intracellar $\mathrm{Pb}$ in wheat roots is similar to that of $\mathrm{Pb}\left(\mathrm{CH}_{3} \mathrm{COO}\right)_{2} \cdot 3 \mathrm{H}_{2} \mathrm{O}$. It is worth noting that the coordinated oxygen atom is not from $\mathrm{Pb}\left(\mathrm{NO}_{3}\right)_{2}$ in solution but from carboxylate functional groups. The coordination number for root samples was particularly low compared to that of $\mathrm{Pb}\left(\mathrm{CH}_{3} \mathrm{COO}\right)_{2} \cdot 3 \mathrm{H}_{2} \mathrm{O}$ because of the high structure disorder of the $\mathrm{Pb}$ coordination shells in root samples. Similar observations for $\mathrm{Pb}-\mathrm{O}$ coordination have been reported for organic macromolecules such as humic acids, fulvic acids or salicylate in soils (e.g., Manceau et al. 1996), for lichen cells exudates such as oxalate and parietinic acid (Sarret et al. 1998), and for lignocellulosic biomaterial (Dupont et al. 2002).

The major conclusions from this study are that (1) the maximum Michaelis-Menten influx rate $\left(V_{\max }\right)$ for $\mathrm{Pb}$ uptake was enhanced by the presence of organic acids; (2) the enhanced influx of $\mathrm{Pb}$ into wheat roots was partially mediated by $\mathrm{Ca}^{2+}$ and $\mathrm{K}^{+}$channels, and depended upon the plasma membrane P-type ATPase; (3) the enhanced uptake of $\mathrm{Pb}$ was attributed to the enhanced diffusion of $\mathrm{Pb}$ towards roots by organic acids; and (4) one $\mathrm{Pb}$ (II) atom was coordinated to four oxygen atoms in wheat roots such that the coordination environment of $\mathrm{Pb}$ in wheat roots was similar to that of $\mathrm{Pb}\left(\mathrm{CH}_{3} \mathrm{COO}\right)_{2} \cdot 3 \mathrm{H}_{2} \mathrm{O}$. This last conclusion supports earlier findings that the binding of $\mathrm{Pb}(\mathrm{II})$ in wheat roots occurs via carboxylic groups. However, we emphasize that our findings were the result of experiments performed with solution cultures and therefore may not be directly applicable to actual field situations.

Acknowledgments This study was supported by the National Natural Science Foundation of China (Grant No. 20237010 and 20177030).

\section{References}

Arazi T, Sunkar R, Kaplan B, Fromm H (1999) A tobacco plasma membrane calmodulin-binding transporter confers $\mathrm{Ni}^{2+}$ tolerance and $\mathrm{Pb}^{2+}$ hypersensitivity in transgenic plants. Plant J 20:171-182

Andreu L, Cornelia IU, Amparo S (2000) $\mathrm{Cd}^{2+}$ effects on transmembrane electrical potential difference, respiration and membrane permeability of rice (Oryza sativa L) roots. Plant Soil 219:21-28

Berkelaar E, Hale BA (2003) Accumulation of cadmium by durum wheat roots: bases for citrate-mediated exceptions to the free ion model. Environ Toxicol Chem 22: 1155-1161

Berne RM, Levy MN (1998) Physiology. Mosby, St Louis, p 1131 Blaylock MJ, Salt DE, Dushenkov S, Zakharova O, Gussman C, Kapulnik Y, Ensley BD, Raskin I (1997) Enhanced accumulation of $\mathrm{Pb}$ in Indian mustard by soil-applied chelating agents. Environ Sci Technol 31:860-865

Bregante M, Carpaneto A, Pastorino F, Gambale F (1997) Effects of mono- and multi-valent cations on the inwardrectifying potassium channel in isolated protoplasts from maize roots. Eur Biophys J 26:381-391

Checkai RT, Corey RB, Helmke PA (1987) Effects of ionic and complexed metal concentrations on plant uptake of cadmium and micronutrient metals from solution. Plant Soil 99:335-345

Cieśliński G, van Rees KCJ, Szmigielska AM, Krishnamurti GSR, Huang PM (1998) Low-molecular-weight-organic acids in rhizosphere soils of durum wheat and their effect on cadmium bioaccumulation. Plant Soil 203:109-117

Clemens S, Palmgren MG, Krämer U (2002) A long way ahead: understanding and engineering plant metal accumulation. Trends Plant Sci 7:309-315

Dupont L, Guillon E, Bouanda J, Dumonceau J, Aplincourt M (2002) EXAFS and XANES studies of retention of copper and lead by a lignocellulosic biomaterial. Environ Sci Technol 36:5062-5066

Essah PA, Davenport R, Tester M (2003) Sodium influx and accumulation in Arabidopsis. Plant Physiol 133:307-318

Godwin HA (2001) The biological chemistry of lead. Curr Opin Chem Biol 5:223-227

Gustafsson JP (2006) Visual MINTEQ version 2.50 KTH, Royal Institute of Technology, Stockholm, Sweden

Han F, Shan XQ, Zhang J, Xie YN, Pei ZG, Zhang SZ, Zhu YG, Wen B (2005) Organic acids promote the uptake of lanthanum by barley roots. New Phytol 165:481-492

Hart JJ, Welch RM, Norvell WA, Sullivan LA, Kochian LV (1998) Characterization of cadmium binding, uptake, and translocation in intact seedlings of bread and durum wheat cultivars. Plant Physiol 116:1413-1420

Huang JW, Cunningham SD (1996) Lead phytoextraction:species variation in lead uptake and translocation. New Phytol 134:75-84

Huang JW, Blaylock MJ, Kapulnik Y, Ensley BD (1998) Phytoremediation of uranium-contaminated soils: role of 
organic acids in triggering uranium hyperaccumulation in plants. Environ Sci Technol 32:2004-2008

Jones DL (1998) Organic acids in the rhizosphere-a critical review. Plant Soil 205:25-44

Kochian LV, Shaff JE, Lucas WJ (1989) High affinity K ${ }^{+}$uptake in maize roots. A lack of coupling with $\mathrm{H}^{+}$efflux. Plant Physiol 91:1202-1211

Kochian LV (1991) Mechanisms of micronutrient uptake and translocation in plants. In: Mortvedt JJ (ed) Micronutrients in agriculture. Soil Science Society of America, Madison, pp 251-270

Lasat MM, Baker AJM, Kochian LV (1996) Physiological characterization of root $\mathrm{Zn}^{2+}$ absorption and translocation to shoots in $\mathrm{Zn}$ hyperaccumulator and nonaccumulator species of Thlaspi. Plant Physiol 112:1715-1722

Laurie SH, Tancock NP, McGrath SP, Sanders JR (1991) Influence of complexation on metal nutrient uptake of plants. I. EDTA in a multi-metal and computer simulation study. J Exp Bot 42:509-513

Leng Q, Merier RW, Yao W, Berkowits GA (1999) Cloning and first functional characterization of a plant cyclic nucleotidegated channel. Plant Physiol 121:753-761

López-Bucio J, Nieto-Jacobo MF, Ramírez-Rodríguez V, Herrera-Estrella L (2000) Organic acid metabolism in plants: from adaptive physiology to transgenic varieties for cultivation in extreme soils. Plant Sci 160:1-13

Ma JF, Ryan PR, Delhaize E (2001) Aluminium tolerance in plants and the complexing role of organic acids. Trends Plant Sci 6:273-278

Manceau A, Boisset MC, Sarret G, Hazemann JL, Mench M, Cambier P, Prost R (1996) Direct determination of lead speciation in contaminated soils by EXAFS spectroscopy. Environ Sci Technol 30:1540-1552

Naidu R, Harter RD (1998) Effects of different organic ligands on cadmium sorption by and extractability from soils. Soil Sci Soc Am J 62:644-650

Pellet DM, Grunes DL, Kochian LV (1995) Organic acid exudation as an aluminum-tolerance mechanism in maize (Zea mays L.). Planta 196:788-795

Qin F, Wen B, Shan XQ, Xie YN, Liu T, Zhang SZ (2006) Mechanisms of competitive adsorption of $\mathrm{Pb}, \mathrm{Cu}$ and $\mathrm{Cd}$ on peat. Environ Pollut 144:669-680

Rehr JJ, Albers RC, Zabinsky SI (1992) High-order multiplescattering calculations of X-ray-absorption fine structure. Phys Rev Lett 69:3397-3400

Rensing C, Sun Y, Mitra B, Rosen BP (1998) Pb(II)-translocating P-type ATPases. J Biol Chem 273:32614-32617
Sarret G, Manceau A, Spadini L, Roux JC, Hazemann JL, Soldo Y, Eybert-Bérard L, Menthonnex JJ (1998) Structural determination of $\mathrm{Zn}$ and $\mathrm{Pb}$ binding sites in Penicillium chrysogenum cell walls by EXAFS spectroscopy. Environ Sci Technol 32:1648-1655

Schmidt W (1999) Mechanisms and regulation of reductionbased iron uptake in plants. New Phytol 141:1-26

Schwarzenbach RP, Gschwend PM, Imboden DM (2003) Environmental organic chemistry, 2nd edn. Wiley, Hoboken, pp $417-422$

Senden MHMN, van der Meer AJGM, Verburg TG, Wolterbeek HTh (1995) Citric acid in tomato plant roots and its effect on cadmium uptake and distribution. Plant Soil 171:333-339

Smolders E, McLaughlin MJ (1996) Chloride increases cadmium uptake in Swiss Chard in a resin-buffered nutrient solution. Soil Sci Soc Am J 60:1443-1447

Srivastava S, Prakash S, Srivastava MM (1999) Chromium mobilization and plant availability-the impact of organic complexing ligands. Plant Soil 212:203-208

Sunkar R, Kaplan B, Bouche N, Arazi T, Dolev D, Talke IN, Maathuis FJM, Sanders D, Bouchez D, Fromm H (2000) Expression of a truncated tobacco NtCBP4 channel in transgenic plants and disruption of the homologous Arabidopsis CNGC1 gene confer $\mathrm{Pb}^{2+}$ tolerance. Plant $\mathrm{J} 24: 533-$ 542

Tomsig JL, Suszkiw JB (1991) Permeation of $\mathrm{Pb}^{2+}$ through calcium channels: fura-2 measurements of voltage- and dihydropyridine-sensitive $\mathrm{Pb}^{2+}$ entry in isolated bovine chromaffin cells. Biochim Biophys Acta. Biomembranes 1069:197-200

Tyerman SD, Skerrett IM (1999) Root ion channels and salinity. Sci Hortic 78:175-235

Vassil AD, Kapulnik Y, Raskin I, Salt DE (1998) The role of EDTA in $\mathrm{Pb}$ transport and accumulation by Indian mustard. Plant Physiol 117:447-453

Wang ZW, Zhang SZ, Shan XQ (2004) Effects of low-molecularweight-organic-acids on uptake of lanthanum by wheat roots. Plant Soil 261:163-170

White PJ (1997) Cation channels in the plasma membrane of rye roots. J Exp Bot 48:499-514

Wu J, Hsu FC, Cunningham SD (1999) Chelate-assisted Pb phytoextraction: $\mathrm{Pb}$ availability, uptake, and translocation constraints. Environ Sci Technol 33:898-1904

Zhang SZ, Shan XQ (1997) The determination of rare earth elements in soil by inductively coupled plasma mass spectrometry. Atomic Spectrosc 18:140-144 